\title{
Corrigendum: Spatial and historic variability of benthic nitrogen cycling in an anthropogenically impacted estuary
}

\author{
Sarah Q. Foster ${ }^{1}$ and Robinson W. Fulweiler ${ }^{1,2 *}$ \\ ${ }^{1}$ Department of Earth and Environment, Boston University, Boston, MA, USA, ${ }^{2}$ Department of Biology, Boston University, \\ Boston, MA, USA
}

Keywords: benthic nitrogen cycling, sediment oxygen demand, net denitrification, Waquoit Bay, historic variability, spatial variability

\section{A corrigendum on}

Spatial and historic variability of benthic nitrogen cycling in an anthropogenically impacted estuary

OPEN ACCESS

Edited and reviewed by:

Paul E. Renaud,

Akvaplan-niva AS, Norway

*Correspondence:

Robinson W. Fulweiler

rwf@bu.edu

Specialty section:

This article was submitted to Global Change and the Future Ocean,

a section of the journal

Frontiers in Marine Science

Received: 02 March 2016 Accepted: 10 March 2016 Published: 23 March 2016

Citation:

Foster SQ and Fulweiler RW (2016)

Corrigendum: Spatial and historic variability of benthic nitrogen cycling in

an anthropogenically impacted

estuary. Front. Mar. Sci. 3:35.

doi: 10.3389/fmars.2016.00035 by Foster, S. Q., and Fulweiler, R. W. (2014). Front. Mar. Sci. 1:56. doi: 10.3389/fmars.2014.00056

The authors would like to provide updated sediment porosity values for the four sampling stations included in Table 1 of the original paper, due to an error in the original calculations. The porosity corrections do not change any of the data interpretations or the text of the manuscript.

For simplicity and clarity, corrections are listed below in bold and underlined font. The page number corresponds to the original paper.

- Page 3. Table 1.

- Childs River Estuary (CRE), Sediment Characteristics, Porosity, 0.46 ( \pm 0.02$)$ changes to $\underline{\mathbf{0 . 6 4}}$ $( \pm 0.02)$

- Metoxit Point (MP), Sediment Characteristics, Porosity, $0.56( \pm 0.02)$ changes to $\underline{0.83( \pm 0.01)}$

○ South Basin (SB), Sediment Characteristics, Porosity, $0.42( \pm 0.01)$ changes to $\underline{\mathbf{0 . 5 9}}( \pm 0.01)$

- Sage Lot Pond (SLP), Sediment Characteristics, Porosity, $0.50( \pm 0.01)$ changes to $\underline{\mathbf{0 . 7 9}}$ $( \pm 0.01)$

\section{AUTHOR CONTRIBUTIONS}

Both authors, SQF and RWF discussed the error and agreed to request the correction. The first draft of the Corrigendum text was written by SQF. RWF read and provided comments on the draft and SQF finalized the text.

\section{REFERENCES}

D’Avanzo, C., and Kremer, J. N. (1994). Diel oxygen dynamics and anoxic events in an eutrophic estuary of Waquoit Bay, Massachusetts. Estuaries 17, 131-139. doi: $10.2307 / 1352562$
D’Avanzo, C., Kremer, J., and Wainright, S. C. (1996). Ecosystem production and respiration in response to eutrophication in shallow temperate estuaries. Mar. Ecol. Prog. Ser. 141, 263-274. doi: 10.3354/meps141263

NOAA. (2012). National Oceanic and Atmospheric Administration, Office of Ocean and Coastal Resource Management, National Estuarine Research Reserve 
System-wide Monitoring Program. Centralized Data Management Office, Baruch Marine Field Lab, University of South Carolina. Available online at: http://cdmo.baruch.sc.edu/data/citation.cfm

Valiela, I., Collins, G., Kremer, J., Lajtha, K., Geist, M., Seely, B., et al. (1997a). Nitrogen loading from coastal watersheds to receiving estuaries: new method and application. Ecol. Appl. 7, 358-380. doi: 10.1890/10510761(1997)007[0358:NLFCWT]2.0.CO;2

Valiela, I., Geist, M., McClelland, J., and Tomasky, G. (2000). Nitrogen loading from watersheds to estuaries: verification of the Waquoit Bay nitrogen loading model. Biogeochemistry 49, 277-293. doi: 10.1023/A:10063450 24374
Conflict of Interest Statement: The authors declare that the research was conducted in the absence of any commercial or financial relationships that could be construed as a potential conflict of interest.

Copyright (c) 2016 Foster and Fulweiler. This is an open-access article distributed under the terms of the Creative Commons Attribution License (CC BY). The use, distribution or reproduction in other forums is permitted, provided the original author(s) or licensor are credited and that the original publication in this journal is cited, in accordance with accepted academic practice. No use, distribution or reproduction is permitted which does not comply with these terms. 


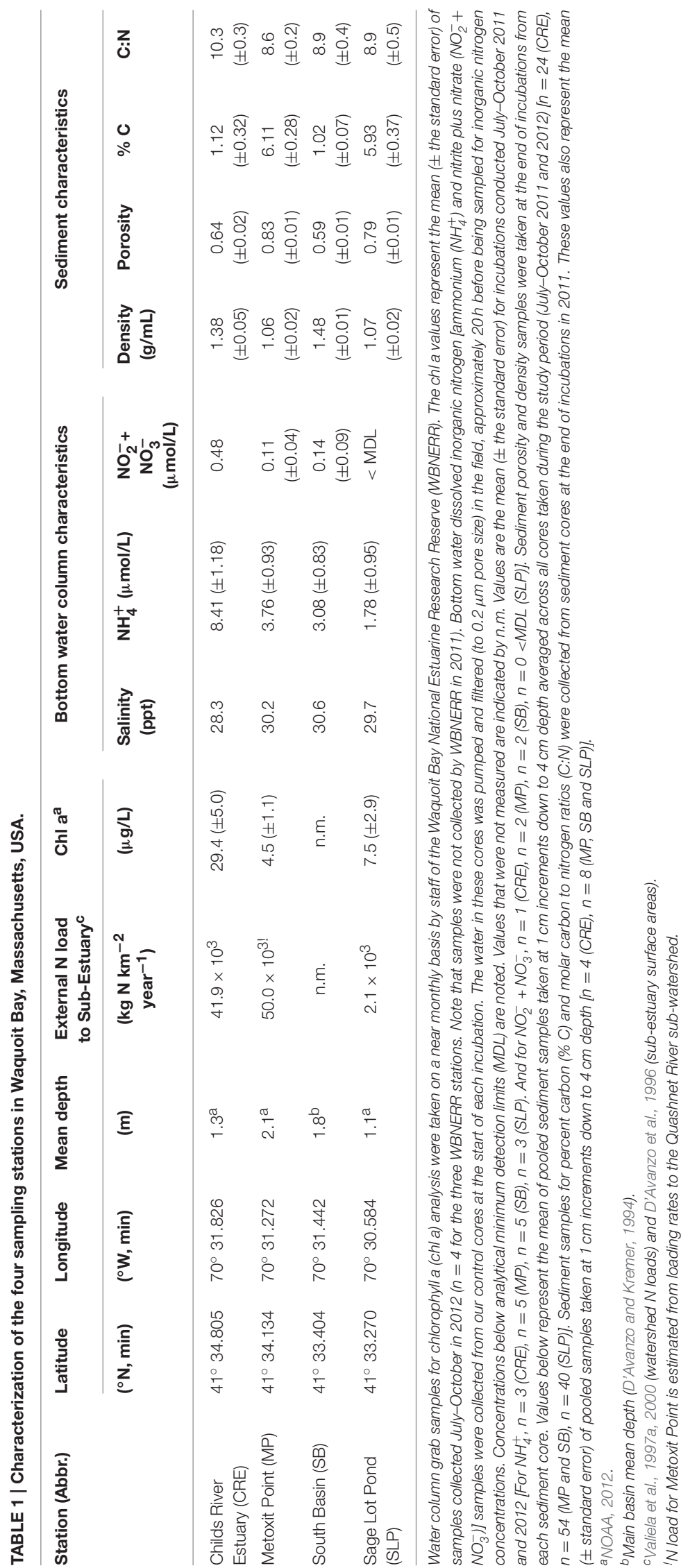

